\title{
Integrated assessment of soil quality after application of the biogas fermentation residues - a laboratory experiment
}

\author{
Arkadiusz Telesiński ${ }^{1,}{ }^{*}$, Krystyna Cybulska ${ }^{2}$, Maciej Płatkowski ${ }^{1}$, Michat Stręk $^{1}$, Grzegorz \\ Jarnuszewski ${ }^{3}$, Ilona Wrońska ${ }^{2}$, Piotr Mularewicz ${ }^{4}$, Tomasz Kajdan ${ }^{4}$, Robert Biczak ${ }^{5}$ and \\ Pawet Kołosowski ${ }^{6}$ \\ ${ }^{1}$ West Pomeranian University of Technology, Faculty of Environmental Management and \\ Agriculture, Department of Plant Physiology and Biochemistry, ul. Słowackiego 17, 71-434 Szczecin, \\ Poland \\ ${ }^{2}$ West Pomeranian University of Technology, Faculty of Environmental Management and \\ Agriculture, Department of Chemistry, Microbiology and Environmental Biotechnology, \\ ul. Słowackiego 17, 71-434 Szczecin, Poland \\ ${ }^{3}$ West Pomeranian University of Technology, Faculty of Environmental Management and \\ Agriculture, Department of Soil Science, Grassland Management and Environmental Chemistry, \\ ul. Słowackiego 17, 71-434 Szczecin, Poland \\ ${ }^{4}$ Biowatt S.A., ul. Blacharska 2, 61-006 Poznań, Poland \\ ${ }_{5}^{5}$ Jan Długosz University in Częstochowa, Faculty of Mathematics and Natural Sciences, Department \\ of Biochemistry and Ecotoxicology, al. Armii Krajowej 13/15, 42-200 Częstochowa, Poland \\ ${ }^{6}$ West Pomeranian University of Technology, Faculty of Environmental Management and \\ Agriculture, Department of Construction and Use of Technical Devices, ul. Papieża Pawła VI 3, \\ 71-459 Szczecin, Poland
}

\begin{abstract}
The aim of study was to determine the impact of three different biogas fermentation residues on some chemical and biochemical characteristics in sandy soil. The laboratory experiment was carried out on loamy sand. Residues were added to soil samples in the forms of pulp, drought, and granulate at dosages of 10,50 , and $100 \mathrm{~g} \cdot \mathrm{kg}^{-1}$. The reference was the soil sample without residues. On day 28 , the content of macroelements and heavy metals was determined. In addition, on days 1 , $7,14,28$, and 56, the content of biomass and the activities of some hydrolases and oxidoreductases were assayed. Results showed that the application of all fermentation residues caused an increase in most of the chemical parameters. The highest impact on $\mathrm{pH}$ and the content of $\mathrm{C}_{\text {tot }}$, $\mathrm{N}_{\text {tot }}, \mathrm{S}_{\mathrm{tot}}, \mathrm{K}$, and $\mathrm{P}$ was observed in the soil treated with granulate, whereas the increase in the content of heavy metals was the highest after the drought application. The effect of biogas fermentation residues on all hydrolases and $o$-diphenol oxidase activities was mostly significant, but depended on the kind of residues and the day of experiment. Biomass content and the activity of dehydrogenase were increased in the whole experiment.
\end{abstract}

\footnotetext{
*Corresponding author: arkadiusz.telesinski@zut.edu.pl
} 


\section{Introduction}

A by-product in the form of fermentation residue is formed during biogas production. The processing of fermentation residue, for example, by thermal drying, pelletization, and drying with lime, enables the use of the resulting product for fertilization, energy, or others [1].

Fertilizer produced in this way reduces energy consumption and limits greenhouse gas emissions, which contribute to climate protection. The chemical composition of the fermentation residue depends on the substrates introduced into the reactor of a biogas plant [2]. The hydrated fermentation residue is quite strongly mineralized compared with the input substrates, which allows rapid absorption of nutrients by the plants [3]. The fermentation residues can be used to fertilize the soil on which the energy crops are grown. Fermentation residue use for the above purposes allows partial closure of elements flux and may reduce the costs of biomass production [4].

There are many positive effects resulting from the agricultural use of the residue; however, there are also many opponents of that method. They argue their reasons with the fear of bacteria and pathogens present in the fermentation residue. Another argument against the use of residue for fertilization is the odor arising from its dispersion on the field [2].

Currently, an increasing number of studies are being conducted in this field, and technological processes aimed at the use of fermentation residues in agriculture or their processing into high-quality organic fertilizers are being tested [5-7].

The aim of this study was to determine the effect of various forms of fermentation residues from biogas production, raw and processed by Biowatt S.A., Poznań, Poland, on selected chemical and biological properties of sandy soil.

\section{Material and methods}

\subsection{Scheme of the experiment}

The experiment was carried out in triplicate under laboratory conditions. The testing was performed on a soil material collected from the topsoil of Brunic Arenosol in Agricultural Experimental Station in Lipnik $\left(53^{\circ} 24^{\prime} \mathrm{N}, 1^{\circ} 28^{\prime} \mathrm{E}\right)$, located in the West Pomeranian District, Poland. According to the classification by the U.S. Department of Agriculture, the sample was the soil with a granulometric composition corresponding to loamy sand. The soil was air dried and sieved with a mesh size of $2 \mathrm{~mm}$.

Various forms of fermentation residues from biogas production, provided by the technological company Biowatt S.A., specializing in the processing of organic waste into energy and high-quality organic fertilizers, were used in the experiment. The substrate for methane fermentation consisted of corn silage (51\%), pig slurry $(20 \%)$, chicken manure $(12 \%)$, cattle manure $(7.5 \%)$, green rye $(7.5 \%)$, and grains $(2 \%)$. After the fermentation process, the collected pulp was dried and subjected to granulation according to the technology developed by Biowatt S.A.

Fermentation residues were introduced into the soil samples in three forms: pulp, drought, and granulate, in quantities of 10,50 , and $100 \mathrm{~g} \cdot \mathrm{kg}^{-1}$. The reference sample was the soil without an addition of fermentation residues. All soil samples were adjusted to $60 \%$ maximum water-holding capacity, and they were incubated in tightly closed glass containers at a temperature of $20^{\circ} \mathrm{C}$. 


\subsection{Determination of soil chemical properties}

Soil chemical properties were assayed on day 28. Soil $\mathrm{pH}(\mathrm{pH}$ in $1 \mathrm{M} \mathrm{KCl}$, and in distilled water) was determined in the samples using the potentiometric method with a $\mathrm{pH}$-meter. The content of organic carbon $\left(\mathrm{C}_{\text {org }}\right)$ was determined using the Tiurin's method; the content of total potassium and heavy metals $(\mathrm{Cu}, \mathrm{Zn}, \mathrm{Mn}, \mathrm{Ni}, \mathrm{Fe}, \mathrm{Cd}, \mathrm{Pb}$, and $\mathrm{Co}$ ) was determined after mineralization in a mixture of $\mathrm{HNO}_{3}+\mathrm{HClO}_{4}$, using an atomic absorption spectrometer UNICAM-SOLAAR 929, whereas in case of phosphorus, the content was determined using the colorimetric method with MERCK VEGA 400 spectrophotometer. The content of the total sulfur, and total nitrogen $\left(\mathrm{S}_{\text {tot }}\right.$, and $\left.\mathrm{N}_{\text {tot }}\right)$ was determined with an elemental analyzer COSTECH ECS 4010 using gas chromatographic techniques [8].

\subsection{Determination of soil biological properites}

The activity of the selected hydrolytic enzymes, namely, acid phosphatase (EC 3.1.3.2) and alkaline phosphatase (EC 3.1.3.1) [9], and beta-glucosidase (EC 3.2.1.21) [10], as well as oxidoreductive enzymes, namely, dehydrogenase (EC 1.1.1.x) [11] and $o$-diphenol oxidase (EC 1.10.3.1) [12], was determined in the soil samples during the experiment on days 1, 7, 14, 28, and 56. The analyzes were performed using UV-1800 spectrophotometer from Shimadzu Corporation. Furthermore, the content of living microorganism biomass was determined on the same days as per the physiological method of Andersen and Domsch [13].

\subsection{Statistical analysis}

The results concerning the effect of fermentation residues on biological properties of the soil were analyzed statistically using two-way analysis of variance and were complementary compared with post hoc Tukey's HSD test. The experimental factors were the dose and the type of fermentation residues. The analyzes were performed separately for each measurement term. The level of significance was $P<0.05$. Statistical analyzes were performed using Statistica 12.5 software (StatSoft).

\section{Results and discussion}

\subsection{Soil chemical properties}

The chemical properties of the soil were determined on day 28 , which allowed to evaluate the possibility of using the fermetation residues for fertilization purposes. The application of all forms of biogas fermentation residues to the soil resulted in an increase in the soil $\mathrm{pH}$, which grew with an increase in the applied dose. It was the most apparent after the application of granulate (Table 1). A similar relationship was found for the contents of $\mathrm{N}_{\text {tot }}$, $\mathrm{S}_{\text {tot }}$, and $\mathrm{P}$. However, an increase in the $\mathrm{C}_{\text {org }}$ content was found to be similar after the application of drought and granulate. Among the parameters presented in Table 1, the highest increase compared with the control soil was noted for $\mathrm{K}$ after the application of drought at a dose of $100 \mathrm{~g} \cdot \mathrm{kg}^{-1}$ dry matter (DM) (714.4\%). Zheng et al. [14] reported that the digestates may contain large fractions of free $\mathrm{K}$ ions, which, in the case of light, poorly buffered soils may overload the sorption complex and destroy the aggregate. The use of digestate as a fertilizer is considered beneficial because it provides nutrients $(\mathrm{N}, \mathrm{P}, \mathrm{K})$ and improves the structure of the soil with the addition of organic matter [15]. De Neve et al. [16] showed that the $\mathrm{C}_{\text {org }}$ in biogas residues is more stable compared with other organic 
wastes. Moreover, Bardgett and Wardle [17] found that the application of biogas fermentation residues to soil should accurately follow precise agricultural practice bearing in mind the ready availability of $\mathrm{N}$ and the crop $\mathrm{N}$ demand so as to avoid $\mathrm{N}$ loss as $\mathrm{NO}_{3}^{-}$, which could be drained into surface waters, leached into ground waters, or denitrified into gaseous forms. An application of fermentation residues results in the introduction of nutrients into the soil in the forms readily available to plants [18]. This may limit the consequential effects of these fertilizers' activity.

Table 1. Chosen chemical parameters in soil treated with biogas fermentation residues.

\begin{tabular}{|c|c|c|c|c|c|c|c|c|}
\hline \multirow{2}{*}{$\begin{array}{c}\text { Form } \\
\text { of } \\
\text { residues }\end{array}$} & \multirow{2}{*}{$\begin{array}{c}\text { Dosage } \\
\left(\mathrm{g} \cdot \mathrm{kg}^{-1} \mathrm{DM}\right)\end{array}$} & \multicolumn{2}{|c|}{ pH } & \multirow{2}{*}{$\begin{array}{c}C_{\text {org }} \\
\left(\mathrm{g} \cdot \mathrm{kg}^{-1}\right)\end{array}$} & \multirow{2}{*}{$\begin{array}{c}\mathrm{N}_{\text {tot }} \\
\left(\mathrm{g} \cdot \mathrm{kg}^{-1}\right)\end{array}$} & \multirow{2}{*}{$\begin{array}{c}\mathrm{K} \\
\left(\mathrm{g} \cdot \mathrm{kg}^{-1}\right)\end{array}$} & \multirow{2}{*}{$\begin{array}{c}S_{\text {tot }} \\
\left(\mathrm{g} \cdot \mathrm{kg}^{-1}\right)\end{array}$} & \multirow{2}{*}{$\begin{array}{c}\mathbf{P} \\
\left(\mathrm{g} \cdot \mathrm{kg}^{-1}\right)\end{array}$} \\
\hline & & $\mathrm{H}_{2} \mathrm{O}$ & $\begin{array}{l}1 \mathrm{M} \\
\mathrm{KCl}\end{array}$ & & & & & \\
\hline \multicolumn{2}{|c|}{ Control } & 7.02 & 6.45 & 8.71 & 0.88 & 1.55 & 0.14 & 3.45 \\
\hline \multirow{3}{*}{ Pulp } & 10 & 7.21 & 6.63 & 10.20 & 1.56 & 10.30 & 0.14 & 3.98 \\
\hline & 50 & 7.27 & 6.70 & 11.48 & 0.73 & 10.44 & 0.17 & 4.64 \\
\hline & 100 & 7.67 & 7.00 & 13.04 & 1.98 & 10.96 & 0.23 & 4.83 \\
\hline \multirow{3}{*}{ Drought } & 10 & 7.40 & 6.77 & 11.26 & 1.72 & 11.14 & 0.21 & 4.07 \\
\hline & 50 & 7.95 & 7.09 & 14.41 & 2.55 & 11.53 & 0.43 & 4.64 \\
\hline & 100 & 8.19 & 7.64 & 24.81 & 3.88 & 12.22 & 0.61 & 5.11 \\
\hline \multirow{3}{*}{ Granulate } & 10 & 7.41 & 6.80 & 12.31 & 2.06 & 10.89 & 0.21 & 4.26 \\
\hline & 50 & 7.97 & 7.30 & 14.62 & 2.89 & 10.67 & 0.50 & 4.78 \\
\hline & 100 & 8.29 & 7.83 & 23.96 & 4.10 & 11.19 & 0.75 & 6.31 \\
\hline
\end{tabular}

The content of the total heavy metals in the experimental soil was also found to have increased compared with that in the control soil after the application of fermentation residues. The observed effect increased with increasing doses of the fermentation residues. Similar results were obtained by Pilarska et al. [18]. Even after the application of the highest dose, the content of the total of all examined heavy metals was less than the acceptable content of the soil, both in Poland and in the European Union. Moreover, Cd was not detected either in the control soil or in the soil containing fermentation residues. In the case of $\mathrm{Cu}, \mathrm{Zn}$, and $\mathrm{Co}$, the highest increase was observed after drought application (Table 2), whereas an increase noted for $\mathrm{Pb}$ and $\mathrm{Ni}$ was at a similar level in the soil with the addition of pulp and drought. It is difficult to conclude unequivocally as to which of the applied forms of fermentation residues affected the increase in the Mn content to the highest degree. According to Insam et al. [2], just the content of heavy metals and pathogens is one of the major factors limiting the use of fermentation residues as organic fertilizers.

\subsection{Soil biological properties}

The changes to the biological properties of the soil after the application of fermentation residues were not as clear as those of chemical parameters. This is mainly because they were observed over a period of time. Compared with the control soil, the activity of acid phosphatase was subject to a statistically significant increase only on the first day of the experiment after the application of fermentation pulp at a dose of $10 \mathrm{~g} \cdot \mathrm{kg}^{-1} \mathrm{DM}$ and drought at a doses of 10 and $50 \mathrm{~g} \cdot \mathrm{kg}^{-1} \mathrm{DM}$ (by $18.7 \%$ and $12.3 \%$, respectively). An inhibition of this enzyme activity, or no significant effect of fermentation residues, was noted in other cases (Fig. 1A). The highest decrease in acid phosphatase activity compared with the control was observed on the day 14 in the soil containing pulp at a dose of $100 \mathrm{~g} \cdot \mathrm{kg}^{-1} \mathrm{DM}(64.8 \%)$. Alkaline phosphatase activity during the experiment was subject 
to numerous statistically significant fluctuations (Fig. 1B). Attention should be paid to a significant increase in this enzyme activity in the last two measurements in the soil containing drought and granulate at the doses of 10 and $50 \mathrm{~g} \cdot \mathrm{kg}^{-1} \mathrm{DM}$, respectively. Betaglucosidase activity in the soil containing pulp and granulate was usually significantly lower than that in the control soil (Fig. 1C). This effect was most pronounced for a dose of $100 \mathrm{~g} \cdot \mathrm{kg}^{-1} \mathrm{DM}$. Clear stimulation of this enzyme activity during the whole experiment after drought application at a dose of $100 \mathrm{~g} \cdot \mathrm{kg}^{-1} \mathrm{DM}$ should be emphasized (from a level of $36.2 \%$ to $88.1 \%$ ).

Table 2. Content of chosen heavy metals in soil treated with biogas fermentation residues.

\begin{tabular}{|c|c|c|c|c|c|c|c|}
\hline $\begin{array}{c}\text { Form } \\
\text { of } \\
\text { residues }\end{array}$ & $\begin{array}{c}\text { Dosage } \\
\left(\mathrm{g} \cdot \mathrm{kg}^{-1} \mathrm{DM}\right)\end{array}$ & $\begin{array}{c}\mathrm{Cu} \\
\left(\mathrm{mg} \cdot \mathrm{kg}^{-1}\right)\end{array}$ & $\begin{array}{c}\mathrm{Zn} \\
\left(\mathrm{mg} \cdot \mathrm{kg}^{-1}\right)\end{array}$ & $\begin{array}{c}\mathrm{Mn} \\
\left(\mathrm{mg} \cdot \mathrm{kg}^{-1}\right)\end{array}$ & $\begin{array}{c}\mathrm{Pb} \\
\left(\mathrm{mg} \cdot \mathrm{kg}^{-1}\right)\end{array}$ & $\begin{array}{c}\mathrm{Co} \\
\left(\mathrm{mg} \cdot \mathrm{kg}^{-1}\right)\end{array}$ & $\begin{array}{c}\mathrm{Ni} \\
(\mathrm{mg} \cdot \mathrm{kg} \\
\left.{ }^{1}\right)\end{array}$ \\
\hline \multicolumn{2}{|c|}{ Control } & 4.35 & 22.93 & 210.61 & 9.91 & 1.58 & 3.27 \\
\hline \multirow{3}{*}{ Pulp } & 10 & 4.37 & 30.67 & 222.82 & 9.37 & 1.58 & 3.86 \\
\hline & 50 & 4.64 & 31.27 & 239.78 & 11.13 & 1.99 & 4.39 \\
\hline & 100 & 5.73 & 34.75 & 253.18 & 19.86 & 2.28 & 4.64 \\
\hline \multirow{3}{*}{ Drought } & 10 & 4.35 & 31.17 & 231.00 & 9.88 & 2.07 & 4.17 \\
\hline & 50 & 6.31 & 43.17 & 255.54 & 11.56 & 2.22 & 4.33 \\
\hline & 100 & 8.44 & 46.39 & 257.72 & 19.15 & 2.37 & 4.64 \\
\hline \multirow{3}{*}{ Granulate } & 10 & 4.35 & 29.56 & 237.71 & 9.94 & 1.70 & 4.17 \\
\hline & 50 & 4.56 & 32.10 & 252.80 & 10.04 & 2.04 & 4.36 \\
\hline & 100 & 5.23 & 35.56 & 256.38 & 12.01 & 2.12 & 4.37 \\
\hline
\end{tabular}

The application of pulp at all doses to the soil usually did not affect significantly the dehydrogenase activity (except on day 56, when a dose of $10 \mathrm{~g} \cdot \mathrm{kg}^{-1} \mathrm{DM}$ resulted in a statistically significant increase by $42.4 \%$ compared with the control). In turn, drought application at all doses and granulate at doses of 50 and $100 \mathrm{~g} \cdot \mathrm{kg}^{-1} \mathrm{DM}$ caused a statistically significant stimulation of dehydrogenase activity, even reaching $557.9 \%$, during the whole experiment (Fig. 2A). An activity of $o$-diphenol oxidase during the experiment was subject to numerous statistically significant variations (Fig. 2B). However, in the last two terms of measurements, the application of pulp at all doses reduced, whereas the application of drought and granulate increased the activity of this enzyme (Fig. 3B). However, the biomass content after pulp application at a dose of $10 \mathrm{~g} \cdot \mathrm{kg}^{-1}$ during the whole experiment did not change significantly, whereas an application of higher doses usually initially caused an increase, and then a decrease in this parameter value. The most significant increase in biomass content was noted in the soil containing drought at all applied doses (Fig 3C).

Available literature data indicate a differentiated effect of fermentation residues on biological properties of the soil. In their 3-year field experiment, Bachmann et al. [19] demonstrated the negative effect of fermentation residues on the activity of dehydrogenase and alkaline phosphatase. However, most reports indicate an increase in the content of biomass and the activity of various enzymes involved in $\mathrm{C}$ and $\mathrm{N}$ fluxes, such as dehydrogenase, alkaline phosphatase, acid phosphatase, and beta-glucosidase after fermentation residue application as organic fertilizer [20-23]. According to Cybulska et al. [24], then effect of fermentation residue from biogas plant on the biological properties of the soil depends on the timing of components released from the bio-waste. Moreover, the level of enzymatic activity occurring in fermentation residues is determined by the type of components and processes which they undergo [18]. 


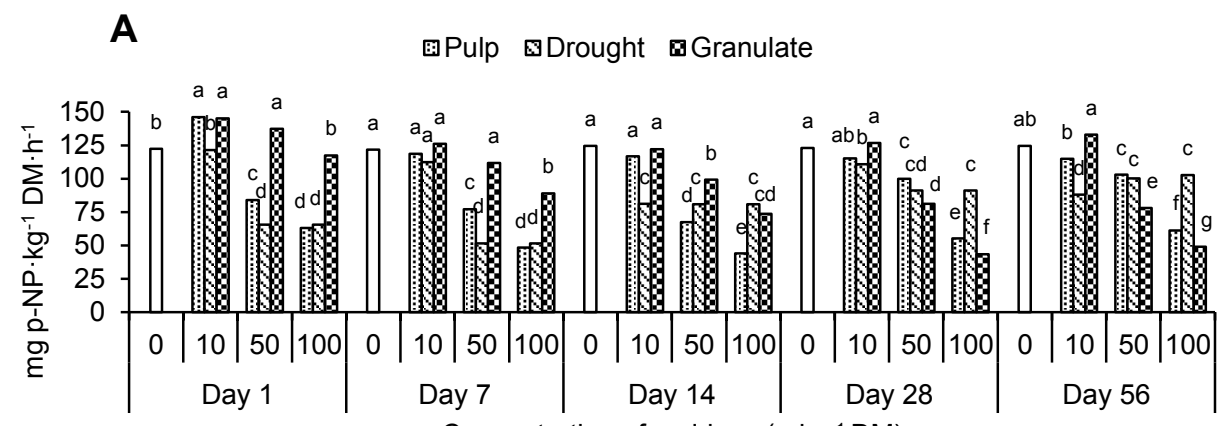

Concentration of residues $\left(\mathrm{g} \cdot \mathrm{kg}^{-1} \mathrm{DM}\right)$

B

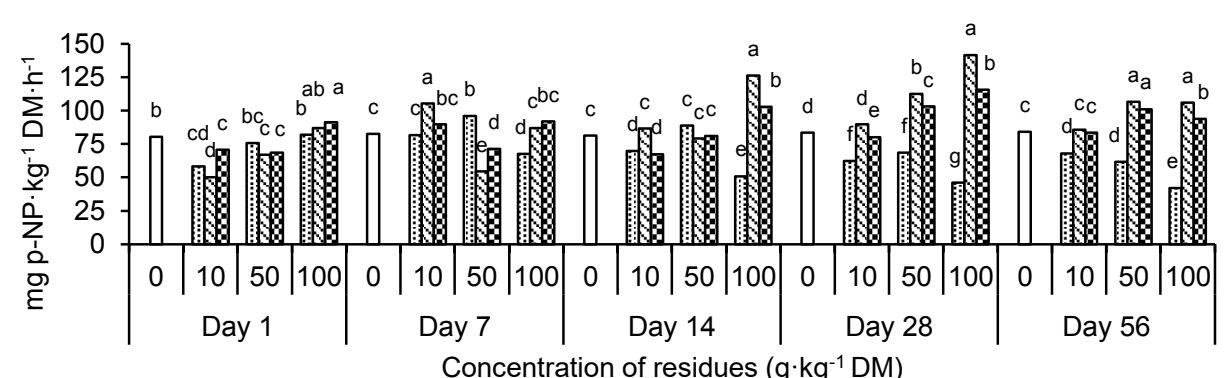

Concentration of residues $\left(\mathrm{g} \cdot \mathrm{kg}^{-1} \mathrm{DM}\right)$

C

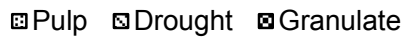

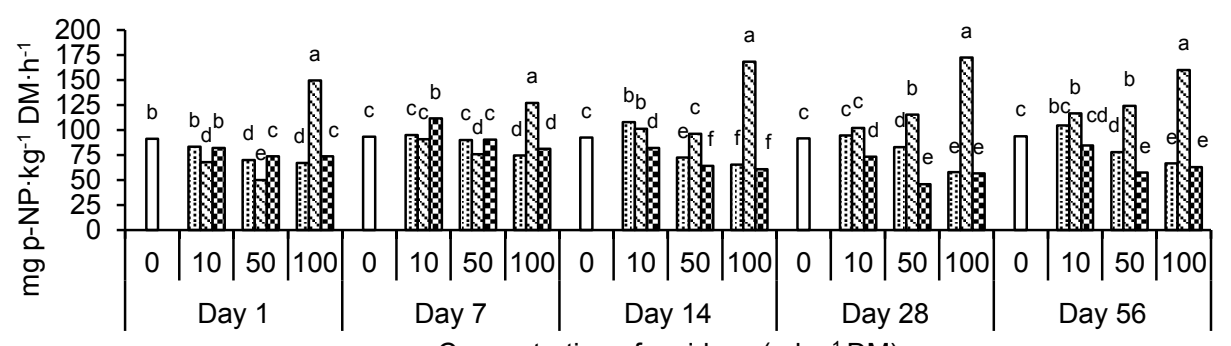

Concentration of residues $\left(\mathrm{g} \cdot \mathrm{kg}^{-1} \mathrm{DM}\right)$

Fig. 1. Activity of hydrolytic enzymes: acid phosphatase (A), alkaline phosphatase (B) and beta-glucosidase $(\mathrm{C})$ in soil treated with biogas fermentation residues; Values denoted with the same letters within the day of experiment do not differ statistically $(P<0.05)$. 


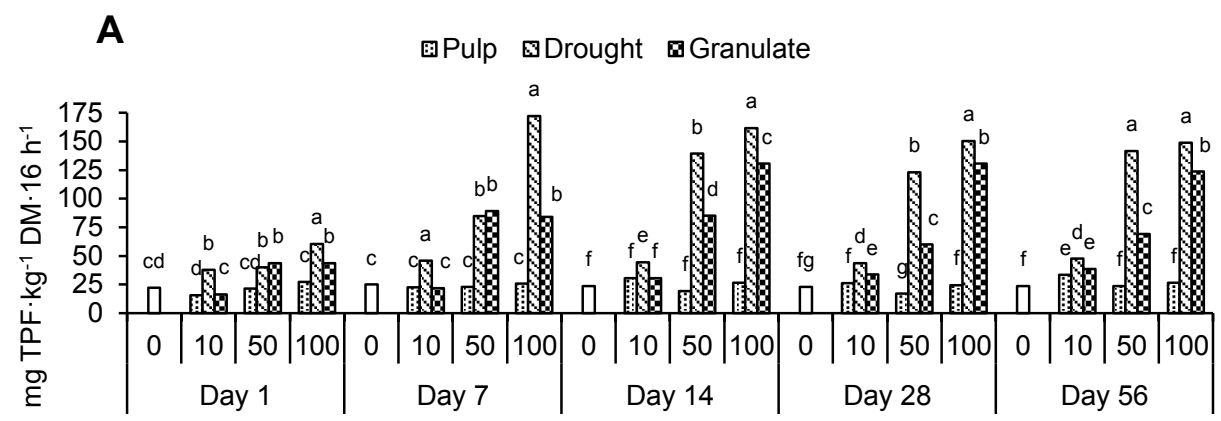

Concentration of residues $\left(\mathrm{g} \cdot \mathrm{kg}^{-1} \mathrm{DM}\right)$

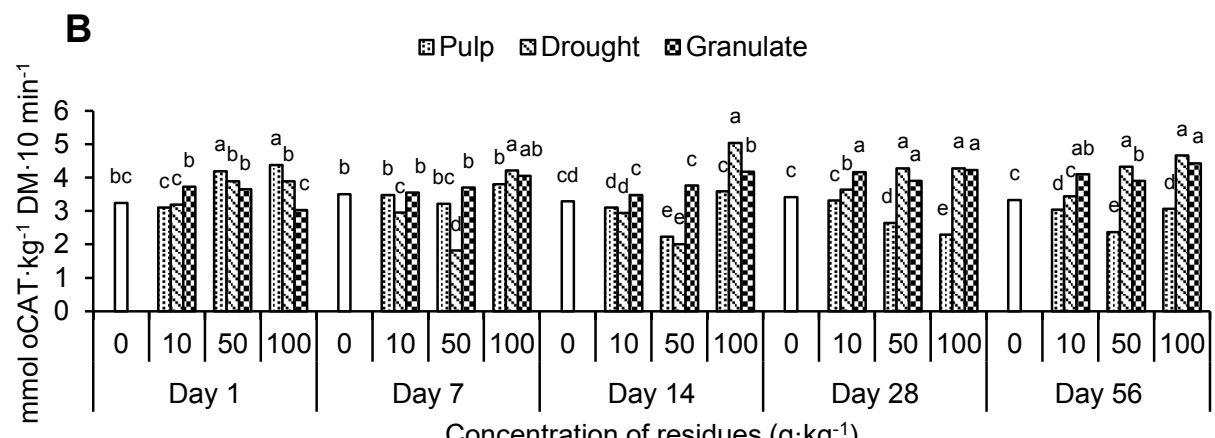

Concentration of residues $\left(\mathrm{g} \cdot \mathrm{kg}^{-1}\right)$

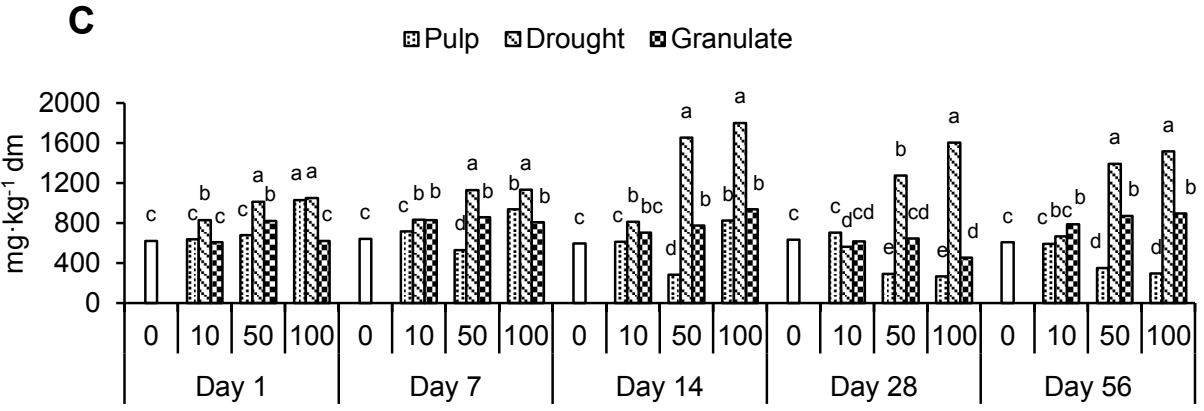

Concentration of residues $\left(\mathrm{g} \cdot \mathrm{kg}^{-1}\right)$

Fig. 2. Activity of oxidoreductive enzymes: dehydrogenase (A), $o$-diphenol oxidase (B) and content of microorganisms biomass $(\mathrm{C})$ in soil treated with biogas fermentation residues; Values denoted with the same letters within the day of experiment do not differ statistically $(P<0.05)$.

\section{Conclusions}

Application of all biogas fermentation residues caused an increase in most of the chemical parameters. The highest impact on $\mathrm{pH}$ and the content of $\mathrm{C}_{\mathrm{org}}, \mathrm{N}_{\text {tot }}, \mathrm{S}_{\text {tot }}, \mathrm{P}$, and $\mathrm{K}$ was observed in the soil treated with granulate, whereas the increase in the content of heavy metals was the highest after the drought application. The effect of biogas fermentation residues on all hydrolase and $o$-diphenol oxidase activities were mostly significant, but depended on the type of residues and the day of experiment. Biomass content and the 
activity of dehydrogenase were found to have increased during the whole experiment, and the highest impact was observed in the soil treated with drought.

\section{References}

1. E. Liu, S. Liu, Renev. Sust. Energ. Rev. 72, 439-444 (2017)

2. H. Insam, M. Gómez-Brandón, J. Ascher, Soil Biol. Biochem. 84, 1-14 (2015)

3. S.V. Borges de Oliveira, A.B. Leoneti, G.M. Magrini Caldo, M.M. Borges de Oliveira, Biomass Bioenerg. 35, 2608-2618 (2011)

4. M. Stefaniuk, P. Bartmiński, K. Różyło, R. Dębicki, P. Oleszczuk, J. Hazard. Mat. 298, 195-202 (2015)

5. J. Abubaker, K. Risberg, M. Pell, Appl. Energy 99, 126-134 (2012)

6. H. Coban, A. Miltner, F.J. Elling, K.-U. Hinrichs, M. Kästner, Soil Biol. Biochem. 86, 108-115 (2015)

7. Q. Jin, Y. Yang, A. Li, F. Liu, A.J. Shan, Clean. Prod. 148, 245-253 (2017)

8. G. Jarnuszewski, Soil Sci. Ann. 67, 1, 24-31 (2016)

9. M.A. Tabatabai, J.M. Bremner, Soil Biol. Biochem. 1, 4, 307-310 (1969)

10. F. Eivazi, M.A. Tabatabai, Soil Biol. Biochem. 20, 601-606 (1988)

11. A. Thalmann, Landwirt. Forsch. 21, 249-258 (1968)

12. R. Perucci, C. Casucci, S. Dumonet, Soil Biol. Biochem. 32, 8-9, 1927-1933 (2000)

13. J.P.E. Anderson, K.H. Domsch, Soil Biol. Biochem. 10, 3, 215-221 (1978)

14. X. Zheng, J. Fan, L. Xu, J. Zhou, Effects of combined application of biogas slurry and chemical fertilizer on soil aggregation and $\mathrm{C} / \mathrm{N}$ distribution in an Ultisol. PLoS ONE 12, 1, e0170491 (2017)

15. R. Nkoa, Agron. Sustain. Develop. 34, 473-492 (2014)

16. S. De Neve, S. Sleutel, G. Hofman, Nutr, Cycl. Agroecosys. 67, 13-20 (2003)

17. R.D. Bardgett, D.A. Wardle D, Aboveground-belowground linkages: Biotic interactions, ecosystems processes, and global change (Oxford University Press, 2010)

18. A. Pilarska, A. Wolna-Maruwka, T. Piechota, K. Pilarski, M. Szymańska, D. Wolicka, Nauka Przyr. Technol. 9, 2, 19 (2015)

19. S. Bachmann, M. Gropp, B. Eichler-Löbermann, Biomass Bioenerg. 70, 429-439 (2014)

20. Y.C. Liang, Y.F. Yang, C.G. Yang, Q.Q. Shen, J.M. Zhou, L.Z. Zang, Geoderma 115, 149-160 (2003)

21. N. Jedidi, A. Hassen, O. van Cleemput, A. MHiri, Waste Manag. Res. 22, 93-99 (2004)

22. J.A. Alburquerque, C. de la Fuente, M. Campoy, L. Carrasco, I. Najera, C. Baixauli, F. Caravaca, A. Roldan, J. Cegarra, M.P. Bernal, Europ. J. Agron. 43, 119-128 (2012)

23. M. Gomez-Brandon, M. Fernandez-DelgadoJuarez, M. Zangerle, H. Insam, J. Hazard. Mat. 302, 267-274 (2016)

24. K. Cybulska, I. Wrońska, T. Kitczak, J. Dłużewska, S. Mahdi Oraibi, H. Czyż, Woda Środ. Obsz. Wiej. 15, 1, 29-36 (2015) 